\title{
Mutinus caninus Huds. and Peziza acetabulum L. in Finland
}

\author{
Yrjö Mäkinen
}

Publications from the Department of Botany, University of Turku, No. 48

1. The species of the family Phallaceae (Fungi, Gasteromycetes) have always drawn the attention of many non-mycologists. Phallus impudicus (L.) Pers. is the only Finnish species of this family which has been thoroughly investigated from the ecological and distributional point of view (LuTHer 1947, LAINE 1955).

Another species can now be added to the Finnish Phallaceaes. In summer 1958 two fruiting bodies of Mutinus caninus Huds. were found in the southwestern archipelago. The locality was the island Jungfruskär in the parish Houtskär in Varsinais-Suomi (Regio aboënsis), which is situated at northern latitude ca. $60^{\circ} 8^{\prime}$, and at eastern longitude ca. $21^{\circ} 3^{\prime}$. Mutinus grew in a Corylus-grove in an open, rather moist place. The ground was covered by mosses, mainly by Climacium dendroides, Thuidium recognitum and Polytrichum commune, the last one indicating the somewhat swampy character of the locality. The fruiting bodies were $8 \mathrm{~cm}$ tall, the diameter of the stem $0.6 \mathrm{~cm}$, and were almost fully developed (fig. 1 a). Although the surrounding vegetation was quite luxuriant, no basocline vascular plants or mosses occurred in the immediate vicinity. In Central Europe, Mutinus caninus is one of the characteristic fungi of the Quercus-Betula woodland (NeuHoff 1956 p. 25) having its main distribution in this type of forest.

In addition, Mr. Toivo Räsänen has sent a specimen of Mutinus that he has collected in Central Finland in the town Kuopio, in the courtyard of the Botanical Museum 11.IX. 1961 (at northern latitude ca. $62^{\circ} 54^{\prime}$ and eastern longitude ca. $27^{\circ} 33^{\prime}$ ) (fig. $1 \mathrm{~b}$ ). In 1962, the fungus was still growing here; the fruiting bodies appeared two times, in the beginning of July and a second time at the end of August.

In Denmark Mutinus caninus is rather common (Ferdinandsen \& Winge 1943 p. 347). In Sweden it has been found several times in the southernmost province Scania (Skåne) (Gertz 1923, Andersson 1940, 1941, Holmberg 1961), but outside of Scania it has been found only once in Halland (ANDERssoN 1941) and once in Uppland (Andersson 1940).

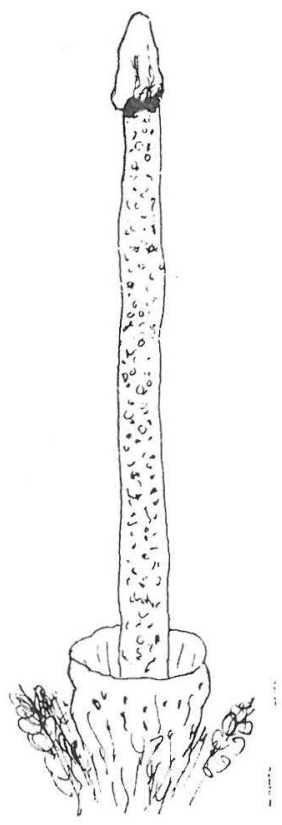

a

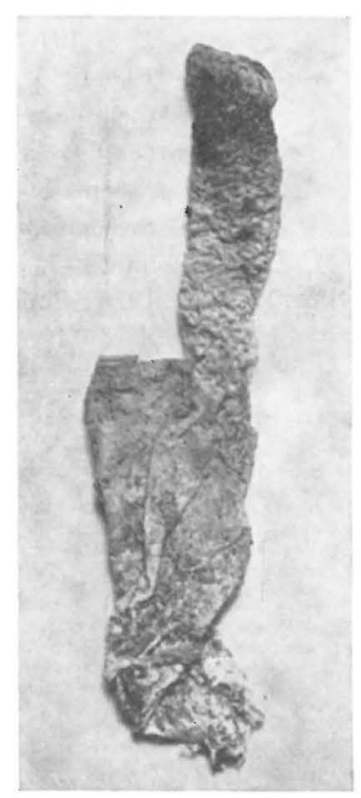

$\mathrm{b}$
Fig. 1. Mutinus caninus: a) redrawn from the original sketch made in Jungfruskär $(1 \times)$; b) photographed from the Kuopio collection $(2.5 \times)$.

In southern Norway, according to FAEGRI (1948), Holgersen (1951), Eakblad \& Wischman (1953) and Eckblad (1955), eight localities are known.The finds in Finland mark the northern limit of the fungus in Europe (fig. 2).

FAEGRI (1948) pointed out, that up to the 1920's Mutinus caninus was quite rare also in Scania, 


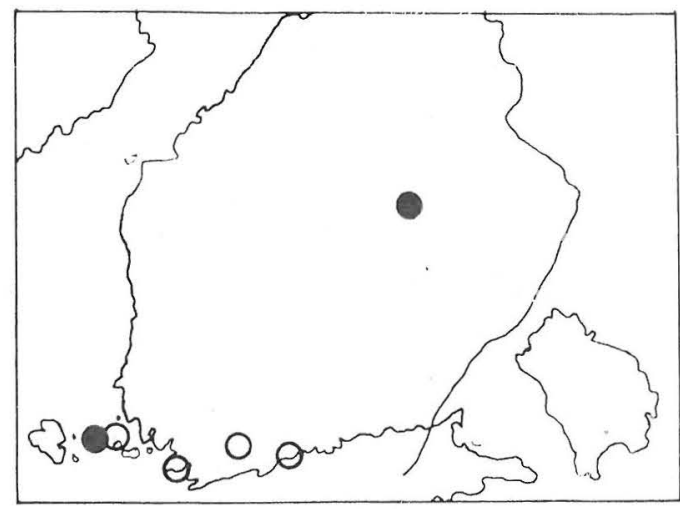

Fig. 2. The finds of Mutinus caninus (dots) and Peziza acetabulum (rings) in Finland.

but has apparently become more frequent in the 1930 's. As all the collections in Norway have been made since 1930, as well as the collection in Uppland, FAEGRI suggests a correlation to the improvement in climate. The new localities in Finland confirm the hypothesis that Mutinus is continuously extending its distribution area, because it is diffucult to imagine that a fungus like Mutinus could have been overlooked.

As a rule Mutinus seems to be confined almost entirely to the mouldering litter of trees, branches and stumps (e.g., Winter 1884 p. 865, Ingelström 1940 p. 215, Andersson 1941, Ferdinandsen \& Winge 1943 p. 437, Faegri 1948). In the island Jungfruskär the substrate was partly decomposed wood, and according to the oral communication by $\mathrm{Mr}$. Räsänen in Kuopio Mutinus grew under Syringa vulgaris.

In addition to Phallus impudicus and Mutinus caninus yet two more Scandinavian species belong to the same family Phallaceae: the originally American Dictyophora duplicata, that has been found in Denmark (Christiansen 1953), in Norway (Eckblad 1955) and in Sweden (Andersson 1950 b, Höjer 1951), and the dune species Phallus hadriani found in Denmark, Norway and Sweden: Andersson 1950 a, Egkblad 1955). Further Skotтsberg (1936) reported the subtropical Lysurus gardneri (Anthurus australiensis) (belonging to the related family Clathraceae), found adventitious near Gothenburg in Sweden, and in Norway (JøRstad 1944), also spread in recent times.

2. Malmström has reported 1941 (p. 189) Peziza acetabulum from Östersundom in southern Finland, Uusimaa (Nylandia), near Helsinki. Three more localities in Varsinais-Suomi (Regio aboënsis) are now known (map in fig. 2). (1) In 1959 (31. V) I found this easily recognisable species (fig. in Malmström 1941, p. 190) in Lohja, Virkkala, Pähkinäniemi (northern latitude ca. 60 $10^{\prime}$ ), growing together with Lathraea squamaria and Neottia nidus-avis in a clayey slope dominated by Aegopodium podagraria; of the bushes Corylus avellana was very abundant. In dried specimens the diameter of the cup is $2-3 \mathrm{~cm}$ and the foot is $1.5-2.5 \mathrm{~cm}$ long and $0.6-0.9 \mathrm{~cm}$ thick. Sahulmann (1960, p. 96) has found the species in the same Pähkinäniemi park in 1958, but apparently not at the exactly same point, as it was growing on a gravel road. (2) Another locality was discovered in the parish Vestanfjärd, when the fungus was found by Mr. Juha Suominen (14.V. $1961)$ in the village of Västerillo, near the limestone quarries in a moist slope covered mainly by spruce (northern latitude ca. $60^{\circ} 2^{\prime}$ ). The 5 or 6 fruiting bodies observed grew in a small cavity under a tree. (3) In 1962 (29.VI.), I found P. acetabulum in the southwestern archipelago, on the island Åvensor, belonging to the Houtskär parish. About 20 fruiting bodies were growing near the old limestone quarries on a rather dry slope, covered by calcareous gravel and dominated by hazel and Filipendula vulgaris. The new localities confirm the concept of MaLMSTRöm, that Peziza acetabulum in Finland is calcicolous and occurs on shady slopes.

I am indebted to Professor Paavo Kallio for many literature references.

\section{LITERATURE GITED}

Andersson, O., 1940: Bidrag till Skånes flora. 7. Notiser om intressanta storsvampar. - Botaniska Notiser 1940, 406-412.

—— 1941: Bidrag till Skånes flora. 10. Notiser om intressanta storsvampar. - Botaniska Notiser 1941, 393-406. -»- 1950 a: Larger Fungi on Sandy Grass Heaths and Sand Dunes in
Scandinavia. - Botaniska Notiser Suppl. 2:2, $1-89$.

Andersson, O., $1950 \mathrm{~b}$ : Bidrag till Skånes flora. 44. Tre för landskapet nya gasteromyceter. - Botaniska Notiser 1950, $69-79$.

Christiansen, M. P., 1953: Ny dansk Lokalitet for Dictyophora duplicata (Slør-Stinksvamp). - Friesia 4, 341. 
Eckblad, F.-E., 1955: The Gasteromycetes of Norway. The Epigaean Genera. - Nytt Mag. f. Bot., 4, 19-86.

$\longrightarrow$ - \& Wrschman, F., 1953: To for Norge nye Phallaceer. - Blyttia 11, $133-139$.

FAegri, K., 1948: Funn av Mutinus caninus i Norge. - Friesia 3, 331-332.

Ferdinandsen, C. \& Winge, O., 1943, Mykologisk Ekskursionsflora. 428 pp. - Ciopenhagen.

Gertz, O., 1923: En ny fyndort i Skåne för Phallus caninus Huds. - Botaniska Notiser 114, 241-244.

Holgersen, H., 1951: To nye funn av liten stinksopp (Mutinus caninus). Naturen $75,190-191$.

Holmberg, U., 1961: Intressanta svampar i Kristianstadstrakten. - Botaniska Notiser $114,241-244$.

HöJer, J., 1951: Dictyophora duplicata i Värmland. - Sv. Bot. Tidskr. 54, 530.

INGELSTRÖM, E., 1940: Svampflora. 216 pp. - Stockholm.

Jørstad, I., 1944: Notes on Norwegian Fungi. 1-3. - Blyttia 2, 33-36.
LAINE, U.,

1955: Haisusienen (Phallus impudicus (L.) Pers.) viimeaikaisesta esiintymisestä Varsinais-Suomen pohjoisosassa. - Luonnon Tutkija $59,8-11$.

Luther, H., 1947: Beobachtungen über Phallus impudicus (L.) Pers. in Finnland. - Mem. Soc. F. Fl. Fenn. $23,42-59$.

Malmström, N., 1941: En för Finland ny Peziza, P. Acetabulum L. - Mem. Soc. F. F1. Fenn. 17, 189-191.

Neuhoff, W., 1956: Die Milchlinge. - Die Pilze Mitteleuropas II b.

Schulmann, O., 1960: Zur Kenntnis der Basidiomyceten Finnlands. - Karstenia V, $5-99$.

Skottsberg, G., 1936: Anthurus australiensis, en för Norden ny Phalloidé. - Medd. Göteborgs Bot. Trädgård 11, $135-157$.

Winter, G., 1884: Die Pilze Deutschlands, Oesterreichs und der Schweiz. I. Abt. - Rabenhorst's KryptogamenFlora, Leipzig.

\title{
Notes on Finnish Myxomycetes
}

\author{
V. Hintikka
}

During the years 1954-62 I have made some occasional collections of Myxomycetes chiefly in Helsinki parish (about $24 \mathrm{~km} \mathrm{~N}$ of Helsinki). Of the species listed below, Physarum psittacinum Ditm. has not been previously recorded from Finland. Dried specimens are preserved in the Botanical Museum of the University of Helsinki and in the Herbarium of Forest Research Institute of Finland.

Ceratiomyxa fruticulosa Macbr. - After long periods of rain not uncommon on rotten wood. Collected in 1959, -58 and -62 .

Physarum psittacinum Ditm. - Helsinki parish, Korso, on mosses, in a rich swamp 9.8.1960. According to R. FRIEs (1912) this species has in Sweden been recorded from several localities.

Physarum viride Pers. - Helsinki, Västersundom, on a rotten stump in a grass-herb-forest, 11.8.1960.

Physarum nutans Pers. - Met with twice on decayed wood in Korso.

Fuligo septica Gmelin - Common in the neighbourhood of Korso.

Leocarpus fragilis Rost. - Fairly common in Korso (8 collections), collected also in Lk: Sodankylä village, 7.8 .58 .
Didymium melanospermum Macbr. - 10 collections from Helsinki parish.

Mucilago spongiosa Morgan - Kerava, Ali-Kerava, on dead shoots of Populus in a herb-rich forest, 9.9.56.

Comatricha nigra Schroet. - Helsinki parish, Simonkylä, on a rotten stump in swampy spruce forest, 12.8.1960.

Lamproderma violaceum (Fr.) Rostk. - Tuusula, Hyrylä, on living stems of Vaccinium myrtillus, 14.5.55. Amaurochaete fuliginosa Macbr. - Korso, on a pine split billet, 26.8.46, on a old pine stump 20.7.54.

Tubifera ferruginosa Gmel. - Helsinki parish and Tuusula, Ruotsinkylä, not rare on old stumps.

Lycogala epidendron Fr. - Very common.

Trichia favoginea Pers. - Tuusula, on a old stump in swampy spruce forest rich in ferns.

Trichia decipiens Macbr. - Collected 5 times on rotten stumps.

Trichia Botrytis Pers. - Nurmijärvi, Raala, in a rich swamp on the bark of a fallen spruce, 29.1.60. Arcyria incarnata Pers. - Korso, on rotten wood, 15.9.60.

Arcyria nutans Grev. - Met with several times on old stumps and logs.

Literature. - Fries. R. E., 1912: Den svenska Myxomycet-floran.-Sv. Bot. Tidskr. 6, 721-802. 